\title{
$\underline{\text { Tolstoy, universalism and the world religions }}$
}

\author{
by DANIEL MOULIN
}

Institute for Culture and Society, University of Navarra

Email:ㄹmoulin@unav.es

This is a draft of an article published in the Journal of Ecclesiastical History, please click here for the final published article

DOI: https://doi.org/10.1017/S0022046916001469

Please cite this article as: MOULIN, D. (2017). Tolstoy, Universalism and the World Religions. The Journal of Ecclesiastical History Volume 68, Issue 3 July 2017, pp. 570-587

\section{Abstract}

Tolstoy was one of the most prolific religious figures of his time. Yet his religious thought and its influence have seldom been explored by Church historians. Drawing upon themes within his literature, non-fiction and previously unconsidered primary sources, this paper considers Tolstoy's religious position in relation to other similar nineteenth-century religious movements. It exposes Tolstoy's links with British Unitarians and also considers Tolstoy's influence upon the founder of Britain's first interfaith organisation, The world congress of faiths. It is argued that Tolstoy provides a paradigmatic example by which to examine the relationship between the legacy of the enlightenment and changing attitudes towards nonChristian religions.

\section{I}

From 1879 until his death in 1910, Leo Tolstoy wrote a series of texts on religious and moral issues that had a far-ranging impact. They were published and promulgated, legally and illegally, by mainstream publishers and radical presses, notably those organised by Tolstoy's secretary and confidant, Vladmir Chertkov. ${ }^{1}$ Tolstoy had always been in some 
sense a seeker, but the focus of his vigorous energy moved from novel writing in the $1860 \mathrm{~s}$ and 1870 s, to the project of articulating his religious views. This change, crisis or conversion has remained divisive among his biographers and critics. ${ }^{2}$ Scholars of Russian literature have tended to interpret Tolstoy's religious views as unique and in some sense incongruous with those of his time. ${ }^{3}$ Philosophers have been dismissive of the substantive claims of Tolstoy's philosophy, which has been understood as an anomaly that soon perished in the nineteenth century's 'ideological battleground' ${ }^{4}$ For example, Isaiah Berlin depicts the mature Tolstoy as an original but stubborn thinker doomed for failure - 'a desperate old man, beyond human aid, wandering self-blinded at Colonus. ${ }^{5}$

However, like those from Western Europe with whose thought he engaged, such as Coleridge, Arnold, Carlyle, Mill and Comte, Tolstoy can be understood as one of the great pathfinders that characterised his age. ${ }^{6}$ As were his contemporaries, Tolstoy was heavily influenced by the philosophers of the Enlightenment, plagued with doubts about orthodox Christianity, dissatisfied with the philosophy of materialism, and horrified by the social impact of industrialisation. His solution to the problems posed by the times was to give up on both materialism and religious orthodoxy to finally adopt, as one commentator calls it, 'a kind of ethical consciousness" ${ }^{7}$ or, as I go on to demonstrate, a kind of unitarian universalism. Tolstoy was deeply reflective about the course of this intellectual and spiritual journey (which he reconstructs in $A$ confession). ${ }^{8}$ In the reply to his later public excommunication, he compared its course to Coleridge's, declaring: 'I began by loving my Orthodox faith more than my peace, then I loved Christianity more than my Church, and now I love truth more than anything in the world.' 9

Owen Chadwick argues that Tolstoy's writings had a part to play in the 'something' that 'happened to religious people which affected their attitude to the world' during the secularisation that occurred in the late nineteenth century. ${ }^{10}$ In a manner similar to Mark 
Bevir's treatment of Annie Besant in this journal, I argue, by considering Tolstoy's intellectual and spiritual path, we can understand the reasons some people began to eschew orthodox Christian beliefs and practices in order to take up a new understanding of spirituality, and how beliefs about the equality and sameness of religions became widespread. ${ }^{11}$ Bevir observes that, although intellectual biography cannot account for the impact of the enormous political, economic and social changes of the nineteenth century, a study of the course of one individual's thought can enable valuable analyses of the choices made in answer to the dilemmas raised by these changes. A study of Tolstoy is appropriate in this regard because his story shows how the spiritual journeying of elites can be interrelated, how their ideas may be received, mutate, but pass across generations, and how they may impact on wider society. For Tolstoy was not at all alone in his journey or elements of its conclusions; others followed him at all levels of society. Admirers who are key to his bilateral connections to the Anglophone world were Louise and Aylmer Maude, his English translators, and the American, Ernest Crosby. ${ }^{12}$ They shared in common the impulse to start a new life as a consequence of reading Tolstoy - a vocation enthusiastically taken up by the Tolstoyan colonists led by John Kenworthy. ${ }^{13}$ Those elites and radical thinkers in the subsequent generation who also engaged with, and drew upon, Tolstoy, as they forged their own distinct intellectual trajectories, include some of the twentieth century's leading international figures: John Dewey, Ludwig Wittgenstein, Gilbert Murray, members of the Bloomsbury group and Mohandas K. Gandhi. ${ }^{14}$ Tolstoy’s influence on Gandhi and pacifists has been thoroughly demonstrated (we can trace this across generations, from Tolstoy (18281910), to Gandhi (1869-1948), to Martin Luther King (1929-1968), for example.) ${ }^{15}$ The purpose of this paper is to gain further conceptual purchase of Tolstoy's understanding of world religions, how he came to this position, and how it may relate to other threads in the nineteenth century's rich tapestry and their further continuance into the twentieth. By 
drawing upon some unconsidered primary sources, I emphasise in particular two hitherto unexamined connections in this regard: Tolstoy's connection with British Unitarians, and his influence upon Sir Francis Younghusband, the founder of the first interfaith organisation in Britain, The World Congress of Faiths.

There are many influences on Tolstoy's religious thought. His energetic intellect and his universalism prompted a wide engagement with multiple texts and authors. What are of interest in the first instance are its founding principles, which he shares with a nexus of nineteenth- century universalist and unitarian thinkers. By these uncapitalised terms, I mean thinkers who rejected orthodox Trinitarian doctrine; emphasised the innate ability of all human persons to experience God by intuition and experience; and believed non-Christian religions express at least some aspects of the same human experience of God as Christianity. Notable contemporaneous thinkers in this vein, who influenced, and came to similar conclusions as Tolstoy, included William Emery Channing, James Martineau, Henry David Thoreau and Ralph Waldo Emerson.

It should be noted that while Tolstoy grew up in a Russian Orthodox household, he was exposed to Protestant ideas from a young age. One vignette beloved by Tolstoy's biographers for its prophetic synergy with Tolstoy's later life (perhaps so because he recollected it after having set out his religious views concretely), is the 'ant brothers' game he played as a child. This consisted of making a den out of furniture with his siblings in a spirit of affection and imagining the world was free of suffering. Tolstoy, who lost his mother and father at a young age, describes this as his first experience of love, and his first experience of God - 'the love of love, the love of God'. ${ }^{16}$ The English term 'ant brothers' is a translation of the Russian 'muraveinye bratya' which was a corruption of 'moravskie bratya' or Moravian Brethren. ${ }^{17}$ This game originated in the ideas of Tolstoy's older brother 
who had heard of the Protestant movement. It is pertinent that Tolstoy should go on to develop dissenting views not unlike those of Protestant minorities, and that the final conclusion of his philosophy should be the all-encompassing commandment to love. ${ }^{18}$ In his famous essay The kingdom of God is within you, Tolstoy presents his views into the historical tradition of Huss and Chelčicky (the early reformers that influenced the Moravian Church) as well as Luther and the condemned fifteenth-century Dominican, Girolamo Savonarola. ${ }^{19} \mathrm{He}$ considered these figures as having preserved the otherwise lost moral imperatives of the Gospels which had been corrupted by mainstream Christianity.

While Tolstoy repudiated Trinitarian Christianity, it is without doubt that the most enduring and forceful influence upon him were the Gospels, in particular the Sermon on the Mount (Matt. 5). Tolstoy's exegetics took Protestantism's 'dangerous idea' to its extreme; he believed the individual's personal interpretation of the bible was paramount. ${ }^{20} \mathrm{He}$ first began translating the Bible into the vernacular while experimenting in his own progressive school for peasant children before writing War and peace. ${ }^{21}$ This rested on Tolstoy's belief that, as Christ's teaching is intuitively known, if not consciously, one should only believe the parts of the Bible that one finds straightforward and easily understood. ${ }^{22}$ It is for this reason Tolstoy continued to use peasant children's understanding of the Bible (or at least his romanticised view of their understanding) as a hermeneutic tool until his last works. ${ }^{23}$ Tolstoy's method of reading the Bible, as in the Unitarian traditions, led him to believe that following Jesus did not require belief in Jesus' divinity, miracles, the resurrection or the sacraments, but his ethical commandments. Jesus was a moral and ethical teacher, much like the enlightenment Jesus of Jefferson. ${ }^{24}$

Philosophical roots common to Tolstoy and his British and American universalist counterparts were Rousseau and German idealism. Tolstoy was an early disciple of Rousseau, choosing at the age of 15 to wear a medallion portrait of him rather than an 
Orthodox cross. ${ }^{25}$ Tolstoy first encountered German idealism at the University of Kazan when studying for a degree in Oriental Languages that he never completed ${ }^{26} \mathrm{He}$ continued to read Kant throughout his life and considered his thought essential for religious reform. Another important figure is Friedrich Schleiermacher. This link has perhaps been overlooked by scholars because Tolstoy does not refer to Schleiermacher explicitly in his most systematic work of philosophy, On Life, but only in a later essay of $1902 .{ }^{27}$ Nevertheless, Tolstoy enthusiastically read Schleiermacher along with Luther during his pedagogical experiments of the early 1860s, and two volumes of Schleiermacher's collected works can be found at Yasnaya Polyana. ${ }^{28}$ Similarities with Schleiermacher can be readily observed in the definition of religion fundamental to the argument Tolstoy develops in all his religious essays after $1887 .{ }^{29}$ Tolstoy defines religion as a relation to life, the direction of intention prior to rational justification, dependent on the experience of living. 'Religion is a certain relation established by man between his separate personality and the infinite universe or its source. ${ }^{30}$ Schleiermacher, almost a century before, had likewise defined religion as the intuition of the universe or an individual's experience of dependency upon the infinite. ${ }^{31}$

By invoking the binary of the universe or world, and the intuition and orientation of the individual, Tolstoy dismisses philosophy, because one has to assume a relation to the universe before one can embark on philosophy that conceptually supports one's relationship. It is for this reason that Tolstoy ultimately dispenses with the 'pessimistic' thought of Schopenhauer, which had otherwise impressed him. ${ }^{32}$ Schleiermacher's observation of the disconnection between the learned classes and popular culture also pre-empted Tolstoy's views on disingenuousness of the upper classes in comparison to the moral and spiritual integrity of the peasantry. Ilya Repin's famous painting, Leo Tolstoy Barefoot, shows in one neat image, the remarkable consequences of Tolstoy's beliefs in all these respects. He stands 
in peasant garb, his own religious writings in his pocket, solitarily at prayer in the woods, contemplating his inner self and communing with nature - defiantly challenging modernity as well as the established religious, social and economic order. ${ }^{33}$

Chadwick identifies the appeal of the 'Russian novel' in nineteenth-century Europe as the subtle way religion permeated literary themes while being 'hardly articulated.' ${ }^{34}$ Although not returning to traditional religious orthodoxy, Russian literature affirmed fundamental truths inexplicable to Victorian materialism. This pertains to the literary vignettes to be later considered in this paper, and accords with the interpretation of Tolstoy as in some sense unitarian. However, it is not the 'Russian' aspect of the novel that necessarily lends this quality. Tolstoy's religious views were compatible with popular strands within Western European and North American thought, and indeed with British literature, such as Dickens. Tolstoy's commentators have sometimes overlooked the subtle religious meaning in his novels that contrast with his more obvious later writings, attributing the latter to the madness of his 'inconstant genius'. ${ }^{35}$ However, an alternative analysis is more cogent. That is, the creative investigation of protagonists' spiritual sentiments and experiences in the novels are powerful examples of the universalism that he would later articulate more overtly. Indeed, Tolstoy's psychology, appropriated from Rousseau and German idealism, can be seen as the premise upon which his famous descriptions of the interior lives of his protagonists are based. ${ }^{36}$ According to this interpretation, his religious views espoused after the novels represent a change of degree rather than category.

Tolstoy shares with the American Transcendentalists and romantic poets the project of investigating the subjective experiences of Kantian categories - that is, moments when ordinary life breaks to allow God to be apprehended through wonder at the glory of the created order, and the force of the innate categories of moral understanding. ${ }^{37}$ There are many examples. Here I consider only two vignettes. The first of these appears in Youth, one 
of Tolstoy's earliest works, written in $1857 .{ }^{38}$ As part of a wider treatment of the young protagonist's moral and social development in the tradition of Bildungsroman, the narrator, Nikolai, looks up to the moon and feels the presence of God in the power and grandeur of nature.

...the more I gazed at the high full moon the more lofty did real beauty and happiness appear to me and the higher and purer to Him, to the source of all beauty and bliss; and tears of unsatisfied but agitating joy rose to my eyes.

And still I was alone and still it seemed to me that this mysterious majestic nature attracting to itself the bright circle of the moon that seemed to stand at a high uncertain spot in the pale blue sky and yet was present everywhere and seemed to fill an immeasurable space, and I, an insignificant worm already defiled by all sorts of mean, paltry, human passions but with a boundless, mighty power of love - at those moments it seemed to me that nature, the moon, and $I$, were all one and the same. ${ }^{39}$

This passage shows the Schleiermacherean (and Tolstoyan) 'sense of union of the individual with the universe. ${ }^{40}$ Nikolai comes to a moral conclusion about his orientation to the universe - that of love - through both an aesthetic experience of that which is without him, and through a consideration of his conscience within him, brought about by that experience. All of Tolstoy's single male protagonists go through similar experiences which can be juxtaposed with their experience of organised religion. This is most apparent in Tolstoy's depiction of the sacraments, the most extreme example being his satire on the Eucharist in Resurrection, which precipitated his public excommunication. ${ }^{41}$

A second pertinent example illustrates how Tolstoy's view of the primacy of religious experience pertains to his universalism. At the end of Anna Karenina, in a typical episode of the kind discussed above, Levin stands out on the terrace of his country house (resembling Yasnaya Polyana) pondering the awesome power and unfathomable nature of 
God. As Levin looks at the Milky Way he begins to question the meaning and implications of the existence of non-Christian religions in relation to his experience. He thinks to himself:

Yes, the one clear unquestionable manifestation of the divinity are the laws of goodness, which have been presented to the world through revelation, which I feel within myself, and through recognition of which I do not so much unite, but am united with, other people whether I like it or not of believers, which is called the Church. 'Well what about Jews, Muslims, Confucians, Buddhists - what are they?' He pondered putting to himself the very question he found dangerous. ${ }^{42}$

Levin in the context of his innate sense of right and wrong is concerned by the tension between the exclusive truth claims of religion revealed through scripture, and the existence of other religions. In his non-fiction, Tolstoy identified and rejected two principal ways this dilemma could be reconciled. All religions could be rejected, as suggested by the progressive secularists, or only one could be embraced, as urged by religious conservatives. Tolstoy polemically labels these vying groups as the 'Scribes' and 'Pharisees' respectively. ${ }^{43}$ Faced with these two belief options, Tolstoy chooses a third option that falls between them, that is, a revised Christianity compatible with reason freed from the fetters of authority (particularly the unjust State) and crucially, one that is compatible with other religions. ${ }^{44}$ According to Tolstoy, the existence of other religions need not undermine belief in God, but rather give more reason to believe in God, providing the various claims of the religions may be reduced to the same truths. Thus the centrality of conscience and intuition as the essence of religion entailed Tolstoy's answer to the problem of other religions. The existence of other religions must point to a universal religion. These conclusions consolidated Tolstoy's universalism. For in finding the correct religion, that is, the correct relationship between the universe, it followed that knowledge of God may be gained 
through each of the world's religious traditions because they each reflect universal truths about the nature of God, morality, and the human condition.

Tolstoy's universalism came to its most obvious conclusion in his last major work, The calendar of wisdom. ${ }^{45}$ On each page several quotations are arranged to be read on a daily basis. Tolstoy places prophets, philosophers and religious thinkers alongside each other, including Moses, Muhammad, Jesus, Krishna, Buddha and Universalists and Unitarians. All of the selected thoughts enshrine the principle of Tolstoy's vision of the unity of the world's religions: there is a 'true and unchanging law, the law which gives us true direction and forbids us to commit $\sin .{ }^{46}$ The significance of these works to their author cannot be underestimated, even though they have been largely ignored by Tolstoy scholars. They are Tolstoy's antidote to thinking the existence of different religions entails the abnegation of religion, or the need to found a new religion. Tolstoy stressed this to the Bishop of Tula when he visited Yasnaya Polyana in January 1909 to urge Tolstoy to come back to Orthodoxy. Tolstoy read passages of The Calendar to the Bishop, including Channing, Emerson, Thoreau and Kant to prove his desire to increase the piety of ordinary people by showing them the unity between the religions. ${ }^{47}$

\section{III}

It has been suggested Tolstoy's conclusions to his philosophical and religious quest were not on the 'continuum' of ideologies available in his time. ${ }^{48}$ However, Tolstoy was consciously aware of his position in the context of contemporaneous writers and movements. He read voraciously and widely in English, French and German. His religious essays refer to key thinkers of the nineteenth century who tackled the same questions (albeit in a variety of ways), such as Comte, Blavatsky, Schopenhauer, Huxley, Darwin, Spencer, and Müller. While Tolstoy could be hastily critical of these and other thinkers of the time, however, he endorsed the 'Unitarians, Universalists, Quakers' and other 'so-called rationalistic sects' as 
'manifestations' of 'the highest religious teaching known to us.' 49 Tolstoy's knowledge of these and other dissenting and heterodox movements increased with the publication of his religious essays, which prompted further correspondence globally, including a constant stream of visitors to Yasnaya Polyana and communications with several American preachers and writers with liberal and progressive views. ${ }^{50}$ The Yasnaya Polyana library bears testament to this interaction, containing radical literature from the era, such as an extensive collection of the sermons of the defrocked Anglican-turned-radical, Charles Vosey. ${ }^{51}$

Tolstoy was encouraged and influenced by other Universalists; they were also encouraged and influenced by him. This is illustrated by his correspondence with the American Unitarian, Adin Ballou, for example. ${ }^{52}$ In England, the dissenting churches formed the grass roots base from which the English Tolstoyan colonies were formed. The most famous of these, affiliated with the Brotherhood Church in London, was at Purleigh, Essex, where Chertkov and the Maudes were associates. This was not the first Tolstoyan community, however. A Unitarian minister, Herbert Mills, founded one in Starnthwaite, Kendal before it became associated with Kenworthy's consortium. ${ }^{53}$ Tolstoy's friendship with Louise and Aylmer Maude was likely his most significant link with Britain, and through them he became personally acquainted with English Quakerism and English religious movements more generally (Aylmer was the son of an Anglican clergyman, but his wife Louise was a Quaker). The extraordinary efforts of the Maudes and Tolstoy in the evacuation of the Doukhobors to Canada show their dedication to shared liberal Christian beliefs and their support in England. Although not a completely homogeneous group in terms of doctrine, the Doukhobors were monotheistic, stressing the Christ 'within' and rejecting the need for a priestly order and Church hierarchy. They were persecuted by the Russian Government for refusing the military draft. It is unsurprising that Tolstoy, the Tolstoyans and English Quakers took interest in their plight. (As Aylmer Maude observed, 
the 'Doukhobors were, in the eyes of the Tolstoyans, a folk who had well-nigh realised the Christian ideal'). ${ }^{54}$ It was in order to relocate the Doukhobors from the Russian Empire to Canada that Tolstoy returned to novel writing, aided by Louise's English translation and Aylmer's mediation, setting aside the proceeds from Resurrection to the cost of chartering transatlantic steam ships. ${ }^{55}$

In order to further demonstrate Tolstoy's relationships with unitarian and universalist traditions, I would like to point out here hitherto unexplored links between Tolstoy and British Unitarianism. I begin with Tolstoy's love of Charles Dickens who Tolstoy saw read A Christmas Carol and The Boots of the Holly Tree Inn held at St James' Hall, Piccadilly and whose portrait hangs above Tolstoy's desk in Yasnaya Polyana. ${ }^{56}$ Tolstoy connected with Dickens' novels because he considered them to extol 'the true Christian spirit. ${ }^{57}$ Indeed, in Dickens we see the same preoccupation with ethical themes of morality, justice, social criticism, and, what could be called brotherhood, without recourse to the rituals and doctrines of traditional Christianity, as we do in Tolstoy. Dickens's religion is understated as Tolstoy he bore no denominational affiliation - but we know he had Unitarian sympathies. He attended Little Portland Street Unitarian Chapel and visited one of Tolstoy's heroes, William Emery Channing, on his visit to America. ${ }^{58}$ A corollary of Tolstoy's universalism was his dislike of division among believers, or exclusive claims to truth. Consequently, he disbelieved in any necessity or virtue of a new religion. To create a sect was paradoxical, a belief he seems to have shared with Dickens and Martineau. ${ }^{59}$ (This is the reason Tolstoy never encouraged the founding of the Tolstoyan communities.)

Tolstoy also valued English attitudes to child rearing (according to one source because English methods impressed upon the child the "consciousness of its powerlessness in the presence of nature'). ${ }^{60}$ It is for this reason that Tolstoy employed several English Governesses at Yasnaya Polyana. ${ }^{61}$ At least one of these Governesses seems to have been a 
Unitarian. An 1883 edition of the British Unitarian organ, The Inquirer, includes a letter from the charismatic Unitarian minister Robert Rodolph Suffield, explaining how a member of his congregation in Reading had been tending to Tolstoy's children; how Tolstoy had reached similar conclusions as Unitarianism; and that he was searching for a replacement au pair. ${ }^{62}$ Suffield does not mention the name of the 'young lady' from his congregation in his letter, but in the archive of Harris Manchester College, Oxford, a copy of a hand-written ledger includes the additional information of the name Emily Tabor. ${ }^{63}$ Tolstoy's children remember Tabor. Tatyana says that she was the niece of the sister-in-law of the Tolstoys' favourite English Governess, Hannah Tarsey. ${ }^{64}$ More significantly, Tatyana says her mother communicated with the same clergyman - presumably Suffield - to find Tabor, who had also arranged Tarsey's appointment. ${ }^{65}$ Although we cannot be sure what influence, if any, the Governesses had upon Tolstoy's religious views, the similarity of Tolstoy's religious position and that of British and American Unitarians cannot be disputed. ${ }^{66}$ By 1909, Tolstoy was advocating Channing's views to the extent that he thought they should be taught to children as a matter of course. ${ }^{67}$ The connection with Suffield is apposite as it shows how other people were making religious choices similar to Tolstoy's - and for similar reasons. Suffield had left the Dominican order after corresponding with Martineau and then attracted huge congregations as minister at Reading Unitarian Chapel. ${ }^{68}$ Like Tolstoy, he had been impressed by Rousseau at an early age and believed in the unity of humankind and of the religions. (They all belonged to 'the Cosmic Faith, the universal foundation, the universal religion.' $)^{69}$

Tolstoy's views and the publication of his religious essays also led to his engagement with religious reformers and groups outside Christianity, including Chinese and Indian religious traditions. ${ }^{70}$ Initiating interlocution with non-Christian religions was a la mode among Universalists and some Unitarians. The Parliament of World's Religions, held in 
Chicago in 1893 is recognised as the first attempt to bring the world's religions together. This inspired other meetings, including one held in Paris in 1900 organised by Bonet Maury, a French Unitarian and participant at the Chicago Parliament, to which Tolstoy declined his invitation - stressing that he believed religion should be an individual activity. ${ }^{71}$ It is of note that Tolstoy had for some years preceding his conversion discussed religion with Jews and Muslims - the latter with Sunni Bashkir nomads during his visits to the steppes. An example of Tolstoy's speculative and idiosyncratic approach to interreligious encounters is given in an account of a local Jewish visitor to Yasnaya Polyana in 1902, who on asking questions about Tolstoy's religion, prompted an impromptu comparison of the Talmud and Matt. 22, from which Tolstoy inferred the parable of the marriage feast was relevant to the international democratisation of the Kingdom of Heaven. ${ }^{72}$

Tolstoy showed a particular interest in religious movements and figures that held beliefs similar to, or compatible with, his own. Of these, Tolstoy's correspondence with Gandhi is well known (Gandhi had written to his pacifist mentor from 'Tolstoy Farm' which he had founded in South Africa after reading The Kingdom of God is Within You.) ${ }^{73}$ Two of Tolstoy's lesser known interactions were with the Baha'i and the Ahmadiyya movements. Both had emerged out of Islamic cultures in Tolstoy's lifetime and shared his project of synthesising the world's religions into an overarching narrative of shared spiritual foundations. Tolstoy read about Baha'i in a pamphlet given to him by his Turkish translator. ${ }^{74}$ A companion of Mirza Ghulam Ahmad (considered a messianic figure by the Ahmadiyya), Dr Mufti Muhammad Sadiq, sent Tolstoy two photographs and a copy of Review of Religions - a periodical which contains studies of world religions from an Ahmadiyya perspective. ${ }^{75}$ Tolstoy may have been confused about the two movements; he wrote to the editor of the Ahmadiyya Review of Religions and asked for more information 
about the Baha'i. ${ }^{76}$ He later voiced disagreements about both, although his letters show a polite endorsement of the universalist principles they espoused.

Tolstoy's vision of the unity of the world's religions lasted beyond his own lifetime and his own correspondence. One pertinent example of the transference of his ideas across generations in this respect is his influence upon the life and work of Sir Francis Younghusband. ${ }^{77}$ Like Tolstoy, Younghusband was first a soldier. His early career was spent exploring the remote Himalayas between the British and Russian Empires, dallying in the Great Game, and then, when promoted to Colonel, leading the disastrous British mission to Tibet in 1904. His black leather notebook written in Chitral in the summer of 1894 demonstrates the extraordinary effect of Tolstoy's writings upon him (although this did not prevent his later controversial military campaign). ${ }^{78}$ After falling from his horse and reading The kingdom of God is within you during convalescence, Younghusband began to question everything. His first entry of 27 August shows some resistance to Tolstoy's pacifism, perhaps unsurprising for a colonial officer at the height of British imperialism, but by 31 August he had resolved, in Tolstoyan fashion to:

...lead a freer life when I can, true to myself and to that divine spark within me as in to thoroughly and sincerely seek first the kingdom of God that is lead a spiritual life developing to the utmost in spirit - the portion of God that is within me. ${ }^{79}$

These aims remain a theme in Younghusband's notebook (and indeed his life thereafter), but he deliberates as to the best practical way he can achieve his goals. His resolutions jotted at the back of the book indicate his tentative plans of living self-sufficiently in a cottage, to explore religions other than Christianity, to travel all over the world, and to try and find deep insights into human nature. Tolstoy is preoccupying him throughout this period, subverting even his supervision of a military parade: 'I can never even look at soldiers now without thinking of Tolstoy's saying that they are "hypnotised men"”. ${ }^{80}$ Younghusband's ideals and 
activity finally came to fruition in the founding of the first interreligious organisation in the British Empire, The World Congress of Faiths. ${ }^{81}$ The organisation still exists, and its work in the 1930s, when Younghusband was still alive, was highly influential. Congresses held in London, Oxford, Cambridge between 1936-1939 comprised representatives of all the world's main religious traditions (including luminaries such as the first President of India and Professor of Eastern Philosophy at Oxford, Sir Sarvepalli Radhakrishnan and Dr Suzuki, the celebrated Japanese Zen Buddhist. ${ }^{82}$ In a book about his motivations for this enterprise, written forty years after his diary entries of 1894, Younghusband still cited Tolstoy as a key inspiration. ${ }^{83}$ In retrospect, he puts Tolstoy's influence into the context of others, such as Emerson and the Sermon on the Mount, and further experiences (and Tolstoyan interpretations of those experiences) that revealed to him the closeness of the unity of men'. ${ }^{84}$ These experiences included being hit by a motor car; experiencing 'unbearable ecstasy' alone on a Tibetan mountainside; and one night in bed being overpowered by 'the Spirit.' Younghusband explains, echoing Tolstoy's definition of religion, that over time these experiences and ideas distilled into a coherent 'conception of the universe and our relationship to it.. ${ }^{85}$

Given Younghusband's high regard for Tolstoy, it is perhaps not surprising that, at the 1937 Congress of Faiths held in Oxford, Aylmer Maude was an active participant. Records show Maude representing and articulating the views of Tolstoy (the 'real religious force' of Russia), which he felt were relevant to several debates. ${ }^{86}$ These contributions were broadly unitarian in perspective, namely, that: ethics were necessarily connected with religion; religion should be based on reason; that God was one and indivisible, and somehow sense of God had been lost through organised religion. The coherence of these ideas, and the diverse nexus of people who sympathised with them, mean Tolstoy can be considered as part of the proliferation of universalism in wider British thought. Furthermore, the knock-on influence of 
Younghusband and the World Congresses is germane. For here we see Tolstoyan universalism at work in the fringe of the British Establishment, with considerable consequences for the mainstream. For example, one participant at the London Congress, Alan Watts, would go onto to take an active role in the organisation, and to become one of the twentieth century's most influential proponents of Buddhism in Western popular culture. ${ }^{87}$ Another interesting outcome of Younghusband's endeavours was his inspiration upon the artist, explorer and philanthropist Emily Georgiana Kemp, who, inspired by him in part, donated a universalist-style chapel to Somerville College, Oxford, where members of the 1937 Congress met, and thereby also impacting upon generations of young women, including Margaret Thatcher who sometimes attended liberal Christian services there in order to listen to the Principal, Helen Darbishire preach. ${ }^{88}$

IV

Despite Tolstoy's influence, and the similar views of others at the time, universalism has not gained popularity as a viable theology of religions in mainstream Christian denominations. In the twentieth century the foundations of liberal Christianity were critiqued by Karl Barth. Increased meetings between the religions also found the premise of universalism wanting as a method of coming together. (This is illustrated by the experiences of participants of the 1937 World Congress of Faiths who found that communal acts of worship were problematic). ${ }^{89}$ Indeed, syntheses such as Tolstoy's do not account for the diversity of the world's religions, but rather give a syncretistic narrative that supplants them. For this reason, following the Second Vatican Council, the word 'dialogue' has been increasingly used to describe a mode of interreligious interaction that does not necessitate a convergence of perspectives, but fosters a good conversation. ${ }^{90}$ However, Tolstoy's religious thought and its legacy present a good case of how universalism may pertain to what Owen Chadwick 
identifies as the secularisation of the 'European mind'. For while also being dependent on aspects of traditional Christianity, particularly the Gospels, Tolstoy's writings illuminate in detail how, Christianity, when interpreted through Kant and Rousseau, can transmute into something distinct from, even opposed to, Trinitarian Christianity.

Tolstoy's fame and literary talent give the opportunity to trace the complex reception of his ideas in the social, artistic, intellectual and political context of his time. This influence goes beyond his impact upon immediate emulators and the Tolstoyan colonists (who, as he predicted, were, in most cases, a short-lived fad). For Tolstoy's belief in private spirituality, his assertion of the unity to be found at the heart of the world's religions, his obsession with personal ethics, and his rejection of organised religion, are some of the principal ingredients of the 'global pluralism' that has since emerged in the West. ${ }^{91}$ Elements of these milieux include the popularity of non-Christian religions; the turn to Religious Studies from Theology in education; the use of 'spirituality' in opposition of 'religion'; and the ongoing efforts of interreligious dialogue and ecumenism among the Christian churches. ${ }^{92}$

It is difficult to separate or survey all the various influences at play during this period. There are, of course, other relevant figures, and movements, such as Theosophy, that developed independently from Tolstoy (although Blavatsky claimed Tolstoy as a Theosophist). ${ }^{93}$ These quests for faith, at first extant among elites, then arguably became more widespread with Tolstoy. Tolstoy became a paradigmatic example of a seeker, and one who gained immense popular appeal. Indicative of his reception by some in the Western intelligentsia, it is notable that William James, in his classic treatment of the psychology of conversion, sees Tolstoy's trajectory as an example of positive religious experience, that led from doubt and melancholy, to a fruitful resolution of 'unity and level'. ${ }^{94}$

The prevalence of late nineteenth- and early twentieth-century seekers perhaps demonstrates something was needed that could not be found in the available religious order. 
It could also indicate there was a new perceived worth in the process of seeking itself. Though many nineteenth-century trailblazers ended up with comparable non-conformist conclusions, once they had gone their ways, subsequent generations could go theirs. The emergence of unconventional spiritual seekers in the establishment, such as Younghusband, enabled similar searches for those in different social classes, and religious quests in different directions. This, I argue, characterises one difference between the world after Tolstoy and the one before him. He was part of a chain of intellectuals that followed their own paths, who then enabled further generations to strike their paths across wider horizons of possibilities. One possible such construction, for example, runs from Kant (1724-1804), to Schleiermacher (1768-1834), to Tolstoy (1828-1910), Younghusband (1863-1942), and then Watts (1915-1973). In four generations from Kant we can therefore see how popular and influential cultural movements such as the New Age, western Buddhism, or the Beat Generation are possible. Thus, I suggest Tolstoy's thought may be located in the development of the present 'secular age' - what Charles Taylor identifies as a complex condition whereby, with orthodox religious participation faltering, people may conduct a personal search for meaning only being able understand themselves in the context of multiple, and often opposing, religious positions. ${ }^{95}$

I have constructed a narrative of Tolstoy's 'secularisation story' 96 , to give one partial account of how increased 'religious variation' 97 may have come to be possible in the present. It certainly does not to show that modernity has led to the absence of religious beliefs. Tolstoy earnestly and steadfastly wished to preserve what he considered the most important aspects of Christianity. Most of all, he did not want to dispense with God or Christian morality as he conceived it. Indeed, it is because of his theistic principles and his disgust at contemporary moral and social problems that he dispensed with the Church. From this standpoint, helped by the popularity of his literature, he then encountered and 
communicated with other universalist thinkers. If we zoom out from Tolstoy's story, we see it is located in a web of other similar narratives that we have only touched upon here Martineau, Suffield, Maude, Younghusband. In all these cases we see how more traditional kinds of Christianity gave way to something more universal.

In regard to contemporaneous figures, Tolstoy's relationships can be understood as 'reciprocal'. ${ }^{98}$ Other universalists bolstered Tolstoy's views, while Tolstoy was considered to add credibility to theirs. We see this in Tolstoy's correspondence, his reading, and other religious movements' public identification with Tolstoy's views. Moreover, we see that Tolstoy's position shares the same roots as many of these connections - the postenlightenment turn in Protestant Christianity. This comprised a move from an understanding of Christianity as revealed religion based on Scripture, to one that stressed the primacy of conscience and the importance of individual experience over Church authority. Tolstoy's various writings articulate this theological perspective comprehensively. Thus, in answer to that Tolstoyan question, as famously posed in the epilogue of War and peace, of whether a person changes history, or just plays a minimal part in it, we can see Tolstoy's place in history. Even if he was the author of some of the most beautiful and cogent articulations of a more global pattern, perhaps he is best understood as a label we can tag on to an emergent intellectual trend rather than an odd and isolated religious thinker, with no real antecedent, and little relevance to the present. ${ }^{99}$

Quotations are taken from the English translations cited. I also reference the Russian original in the 90-volume 'Jubilee Edition' of Tolstoy's works, Polnoe sobranie sochinenii, Moscow, 1929-1964, abbreviated as 'PSS'.

The Tolstoy Studies Journal is abbreviated 'TSJ'.

I thank Tony Cross; Robert Whittaker; Bartosz Pawlowski; Maria Stożek; Marcus and Mary Braybrooke; Danila Andreev; Astrid Grue; Anya Wells; Andrey Levitskiy; Ingrid Lunt; 
Richard Pring; Andrew Breeze; the late Terence Copley; Galina Alexseeva; and Sue Killoran for assistance, encouragements or comments during the gestation of this paper. I also thank the Religion and Civil Society Research Group in the Institute for Culture and Society, University of Navarra; St Deiniol's Library; The Philosophy of Education Society of Great Britain; and The Spalding Trust.

${ }^{1}$ Michael J. De K. Holman, 'Translating Tolstoy for the Free Age Press: Vladimir Chertkov and his English manager Arthur Fifield', Seer, 66 (2) 1988, 184-197.

${ }^{2}$ Inessa Medzhibovskaya, Tolstoy and the religious culture of his time, New York 2008.

${ }^{3}$ Richard F Gustafson, Leo Tolstoy: resident and stranger, Princeton 1986.

${ }^{4}$ David Matual, 'The Gospel according to Tolstoy and the Gospel according to Proudhon', Harvard Theological Review, 75 (1), 1982, 117-28.

${ }^{5}$ Isaiah Berlin, The hedgehog and the fox: an essay on Tolstoy's view of history, London 1953,82

${ }^{6}$ Basil Willey, Nineteenth century studies, London 1949.

${ }^{7}$ Natasha Sankovitch 'Readers' experience of repetition in Tolstoy' TSJ 3, 1990, 49-61.

${ }^{8}$ A Confession trans. J. Kentish, Harmondsworth 1987 ['Ispoved', PSS 23, 1879-1880, 1-59].

9 'A reply to the synod's edict of excommunication, and to letters received by me concerning it' in On Life, trans. A. Maude, 1937, 225 ['Otvet na opredeleniye sinoda ot 20-22 fevralya i na poluchennyye mnoyu po etomu sluchayu pisma’ PSS 34, 1900-1903, 244].

${ }^{10}$ Owen Chadwick, The secularization of the European mind in the nineteenth century, London 1975, 258.

${ }^{11}$ Mark Bevir, 'Annie Besant's quest for truth: Christianity, secularism and new age thought, this Journal, 1999, 62-93. 
${ }^{12}$ See Cynthia Wachtell, 'Ernest Howard Crosby’s swords and ploughshares: a lost antiimperialism, anti-militarism and anti-war classic' South central review 30 (1), 2013, 133-154, and Aylmer Maude's A peculiar people: the doukhobors, London, 1904.

${ }^{13}$ W.H.G. Armytage, 'J.C. Kenworthy and the Tolstoyan Communities' in W. Gareth Jones (ed.) Tolstoi and Britain, Oxford 1995, 135-151.

${ }^{14}$ Daniel Moulin, Leo Tolstoy, London 2014.

${ }^{15}$ Michael J. Nojeim, Gandhi and King: the power of nonviolent resistance, Westport 2004.

16 'Recollections' in Recollections and essays trans. Aylmer Maude, Oxford 1937, p.42

['Vospominaniya', PSS, 34, 1902, 392].

${ }^{17}$ Rosamund Bartlett, Tolstoy: A Russian Life, New York 2011, 52-54.

18 Tolstoy scholars have interpreted Tolstoy's entire life and work with the concept of 'brotherhood', see A. Donskov and J. Woodsworth (eds) Lev Tolstoy and the concept of brotherhood, Ottawa 1996.

${ }^{19}$ The kingdom of God is within you and peace essays, trans. A. Maude, Oxford 1936, 81 [Tsarstvo Bozhiye vnutri vas, PSS, 28, 1890-1893, 53].

${ }^{20}$ I take this phrase from A. E. McGrath Christianity's dangerous idea, New York 2007, although McGrath does not discuss Tolstoy in relation to it.

${ }^{21}$ Moulin, op. cit.

22 'How to read the Gospels and what is essential in them.' In On Life, 1935, 205-208 ['Kak chitat yevangeliye iv chem yego sushchnost' PSS, 39, 1896, 113-116].

${ }^{23}$ 'The Teaching of Jesus' trans A. Maude, Recollections and Essays, Oxford 1937, 446-493 ['Ucheniye Khrista' PSS 37, 1909, 97-147].

${ }^{24}$ Ihor Levitsky, 'The Tolstoy Gospel in the light of the Jefferson Bible', Canadian Slavonic Press 21 (3), 1979, 347-355.

${ }^{25}$ Alymer Maude, The life of Tolstoy: the first fifty years, London 1908, 46. 
Schleiermacher, Fichte, Schelling and Hegel, op. cit., 35.

27 'What is religion?' In On life and essays on religion, trans. A.Maude, Oxford 1934, 231

['Cho takoye religiya I v chem sushchnost yeye’ PSS 35, 1902-1904, 161].

${ }^{28}$ Biblioteka Leva Nikolaevicha Tolstogo v yasnoi poliane [Tolstoy's library at Yasnaya Polyana], 3, Yasnaya Polyana 1999.

${ }^{29}$ Gustafson observes a similarity between Tolstoy and Schleiermacher, but fails to note that Tolstoy read him, cited him, or possessed his books. Medzhibovskaya while noting Tolstoy read Schleiermacher does not make any comparison.

30 'Religion and Morality' in On life and essays on religion trans. A. Maude, Oxford 1934, 198 ['Religiya i nravstvennost', PSS 39, 1893-1898, 26].

${ }^{31}$ Friedrich Schleiermacher, On Religion: Speeches to its cultured despisers, ed. R. Crouter, Cambridge, 1988.

${ }^{32}$ On Life, 179.

${ }^{33}$ E. Mossman makes a similar point using another portrait of Tolstoy to illustrate Tolstoy's view of education, 'Tolstoi and peasant learning in the era of the great reforms' in B. Eklof (ed.), School and Society in Tsarist and Soviet Russia, Basingstoke, 1993, 36-69.

${ }^{34}$ Chadwick, op. cit., 247.

${ }^{35}$ Alexander I. Nazaroff, Tolstoy the inconstant genius: a biography, New York 1929.

${ }^{36}$ Donna Orwin observes Tolstoy's use of Cartesian and Rousseauiean philosophy in Tolstoy's early works but not German idealism, see 'Prince Andrei: the education of rational man' Slavic Review, 42 (4), 1983, 620-632.

${ }^{37}$ Medzhibovskaya observes that Tolstoy read a 'dog-eared' French Translation of Kant's Critique of Pure Reason throughout his youth, op. cit., 36. Furthermore, On Life begins with 
a quotation from the opening paragraph of the conclusion of Kant's Critique of Practical Reason, op. cit.

38 'Youth' in Leo Tolstoy Childhood, Boyhood and Youth, trans. L. and A. Maude, Oxford 1947, 221-404 ['Yunost', PSS 2, 1855-1856, 76-226].

${ }^{39}$ Ibid., 348.

${ }^{40}$ I take here a phrase used to describe the Schleiermachean influence on Unitarian and Universalist thought by Andrea Greenwood and Mark W. Harris, An introduction to the unitarian and universalist traditions, Cambridge 2011, 73.

${ }^{41}$ Resurrection, trans. L. Maude, Oxford 1928 ['Voskresheniye' PSS 32, 1889-1899].

${ }^{42}$ Bartlett, op. cit., 820.

${ }^{43}$ Tolstoy invokes this dichotomy throughout his religious essays, beginning in On Life, 19.

${ }^{44}$ Alexandre Christoyannopoulos identifies Tolstoy's thought as thus providing a useful bridge between the religious and the secular, see 'The Golden Rule on the Green Stick: Leo Tolstoy's International Thought for a "Postsecular" Age' in Towards a Postsecular International Politics: New Forms of Community, Identity, and Power, eds. L. Mavelli and F. Petito, London 2014, 81-102

${ }^{45}$ A Calendar of Wisdom trans. Peter Sekirin, London 1997 ['Krug chtenia' PSS, 41-42, 1904-1908].

${ }^{46}$ Ibid., PSS, 41, 333; ibid., 140.

${ }^{47}$ Alexandra Tolstoy, Tolstoy: A Life of my Father, trans. E. Reynolds, New York 1953, 471. ${ }^{48}$ Natasha Sankovitch, op. cit.

${ }^{49 ،}$ Religion and Morality' in On Life trans. A. Maude Oxford 1934, 176-177 ['Religiya i nravstvennost', PSS 39, 1893-1898, 10-11].

${ }^{50}$ Robert Whittaker, “Tolstoy's American preachers: letters on religion and ethics 18861908” TriQuarterly 107-108, 561-629. 
${ }^{51}$ Biblioteka, op.cit.

${ }^{52}$ Robert Whittaker with N.V. Velikanova, 'L.N. Tolstoi i Adin Ballu i ego edinmyshlenniki, Tolstoi i SShA: perepiska, Moscow, 454-482.

${ }^{53}$ Armytage, op. cit.

${ }^{54}$ A. Maude, A Peculiar People, op. cit., 59.

${ }^{55}$ Ibid.

${ }^{56}$ It is sometimes recounted by biographers, that while in London, Tolstoy heard Dickens speak on education. However, it has been argued convincingly that it is likely that Tolstoy heard a reading of a Christmas Carol, see Victor Lucas Tolstoy in London, London 1979. ${ }^{57}$ Leo Tolstoy in a letter to James Ley, 3 Febuary 1904 in K. N. Lomunov 'Lev Tolstoi on English writers' in W. Gareth Jones, op. cit., 43-60.

${ }^{58}$ Michael Slater, Charles Dickens: A life defined by writing, Yale 2009, 643; 180.

${ }^{59}$ Ralph Waller, 'James Martineau: the development of his thought.' in B. Smith (ed.), Truth, Liberty, Religion, Oxford 1986, 225-64.

${ }^{60}$ C. A. Behrs, Recollections of Count Leo Tolstoy, trans. C.E. Turner, 1893, 32. ${ }^{61}$ Bartlett, op. cit., 204.

${ }^{62}$ R. R. Suffield, 'Count Tolstoi' The Inquirer September 8 1883, 572. I am extremely grateful to Tony Cross, former Principal of Harris Manchester College, Oxford, for pointing out this letter to me.

${ }^{63}$ Chapel Histories - Pamphlets Berkshire, Reading Unitarian Free Church C: BER: RED, Harris Manchester College Library, Oxford. Cross believes these notes were copied out of The Inquirer by a Unitarian prisoner in Broadmoor secure hospital at the behest of Dairmuid O’ Rourke, secretary of Reading Unitarian Chapel until its closure and its historian thereafter. Cross thinks Tabor's name is not in the hand of the prisoner and is therefore supplied by Dairmuid O' Rourke. Whether the inclusion of Tabor's name is accurate, based 
upon secondary literature, documentary evidence or oral record is not known. Furthermore, there is a problem ascertaining the dates the unnamed Governess was in Yasnaya Polyana. From Suffield's letter we do not know where she is in September 1883.

${ }^{64}$ T.L. Sukhotina-Tolstaia Tolstoy Remembered, McGraw Hill 1977, 100. ${ }^{65}$ Ibid.,131.

${ }^{66}$ Ben Hellman observes that Tabor's name appears in an early draft of Anna Karenina as an English Governess and suggests Tolstoy may have learnt about the English fairy tale Goldilocks and the Three Bears through her or another English Governess, which he then made famous, see Tolstoy's 'The Three Bears'. The Metamorphosis of an English tale into a Russian national myth Acta Slavica Estonica VI, 2014, 163-173.

${ }^{67} \mathrm{O}$ vospitanii [On upbringing], PSS, 38, 1909, 62-69.

${ }^{68}$ C. Hargrave, The Life of Robert Rodolph Suffield. London 1893

${ }^{69}$ Hargrave, op. cit., 298.

${ }^{70}$ See Derk Bodde, Tolstoy and China Princeton 1950; and, Radha Balasubramanian The influence of India on Leo Tolstoy and Tolsty's influence on India, Lewiston 2013.

${ }^{71}$ Luigi Stendardo, Leo Tolstoy and the Baha'i faith, trans. J. Fox, Oxford 1985, 25

${ }^{72}$ Aylmer Maude, 'My last visit to Tolstoy' in P. Serekin (ed.) Americans in conversation with Tolstoy, Jefferson 2006, 115-125.

${ }^{73}$ Rivett, op. cit.

${ }^{74}$ Luigi Stendardo, Leo Tolstoy and the Baha'i Faith trans. Jeremy Fox, Oxford 1985, 15

${ }^{75}$ For Tolstoy's correspondence with Sadiq, see Manlana Dost Muhammad Shahid, 'Review of religions: a hundred year history of the magazine', Review of Religions 97 (11), 2002, 20 -

22.

${ }^{76}$ L. Stendardo, Leo Tolstoy and the Baha'i Faith, trans. J. Fox, Oxford1985, 33.

${ }^{77}$ Patrick French, Younghusband, London 1994. 
${ }^{78}$ Younghusband Collection, India Office Manuscripts, British Library, London, Mss Eur F197/257.

${ }^{79}$ Ibid.

${ }^{80}$ Ibid., entry for 9 November .

${ }^{81}$ Marcus Braybrooke, Widening vision, Oxfordshire 2013

${ }^{82}$ A. Douglas Millard (ed.), Faiths and Fellowship: Being the Proceedings of the World Congress of Faiths, London 1936

${ }^{83}$ Francis Younghusband, A Venture of Faith: Being a description of the World Congress of Faiths, London 1936

${ }^{84}$ Ibid., p.22.

${ }^{85}$ Ibid., p.23.

${ }^{86}$ The World's need of religion: Being the Proceedings of the World Congress of Faiths, London 1937, 113.

${ }^{87}$ Alan Watts, In my own way, London 1973, 122.

${ }^{88}$ Daniel Moulin, 'A house of prayer for all peoples: the chapel' in A. Manuel (ed.), Breaking new ground: a history of Somerville College as seen through its buildings, Oxford 2013, 3034; Margaret Thatcher, The Path to Power, London 1995, 40.

${ }^{89}$ Yusuf Ali noted that there were 'differences of opinion' at the 1937 Congress over the possibility of shared devotional services, op cit., 165 .

${ }^{90}$ Catherine Cornille (ed.) Criteria of discernment in interreligious dialogue, Eugene 2009.

${ }^{91}$ Ninian Smart, The world's religions second edition, Cambridge 1998, 592.

${ }^{92}$ Daniel Moulin, 'Leo Tolstoy the spiritual educator', International Journal of Children's Spirituality, 13 (4), 345-353.

${ }^{93}$ Maude, Introduction, On Life, op. cit., xi.

${ }^{94}$ William James, The Varieties of Religious Experience, Glasgow 1960, 191. 
${ }^{95}$ Ibid.

${ }^{96}$ I take the term 'secularisation story' from Taylor, op. cit., p.773-336.

${ }^{97}$ Rodney Stark, 'Secularisation: RIP' Sociology of Religion, 60, 3, 1999, 269 [author's emphasis].

${ }^{98}$ Balasubramanian, op. cit.

${ }^{99}$ For a discussion on Tolstoy's view of history, see Illa Stambler, 'Heroic power in Thomas Carlyle and Leo Tolstoy', The European Legacy, 11 (7), 2006, 737-751. 